\title{
LABOR et EDUCATIO
}

nr 5/2017

\section{INNOWACJE}

Krzysztof Chaczko

Uniwersytet Pedagogiczny im. Komisji Edukacji Narodowej w Krakowie

Marta Iwińska

Kraków

\section{Innowacyjne przeciwdziałania marginalizacji grup mniejszościowych na rynku pracy. Uwagi na temat strategii „dwukierunkowej”}

\section{Innovative Counteracting Marginalization of Minority Groups on The Labor Market. Comments on The "Bidirectional" Strategy}

\begin{abstract}
Wstęp
Nie ulega wątpliwości, że polityka społeczna powinna działać na rzecz rozwiązywania istotnych problemów społecznych. Nie ma także sporu co do faktu, iż obecnie coraz częściej mamy do czynienia z procesem marginalizacji społecznej ${ }^{1}$ grup mniejszościowych, i że jest to kwestia znacząca, która ma ponadto „wielostronny i wielostopniowy charakter” (Jasińska-Kania, Łodziński,

${ }^{1} \mathrm{Na}$ potrzeby analizy przyjmujemy, iż pod kategorią marginalizacji społecznej będziemy rozumieli proces pozbawiania osób lub grup uprawnień przysługujących innym osobom lub grupom w określonym społeczeństwie oraz brak możliwości korzystania z tych uprawnień (Kowalak, 2001).
\end{abstract}


2008, s. 243). Mówiąc bardziej szczegółowo, wszelkie mniejszości, migranci czy też osoby o odmiennych orientacjach kulturowych lub religijnych to sektory społeczne wybitnie narażone na procesy dyskryminacji oraz pozbawiania szans uczestnictwa w życiu wspólnot politycznych, w tym szczególnie na rynku pracy. Potwierdzają to badania analizujące funkcjonowanie mniejszości etnicznych na europejskich rynkach pracy (Craig, 2002), zaś Ruth Lister dodaje, iż z taką sytuacją mamy do czynienia w wielu państwach, nawet w tych doświadczonych latami wielokulturowości: „Pomimo wzrastającej dywergencji między doświadczeniami różnych mniejszości etnicznych na brytyjskim rynku pracy, istnieją poważne dowody potwierdzające ich upośledzoną pozycję, jeśli chodzi o bezrobocie, płace oraz jakość pracy" (Lister, 2007, s. 82). Mało tego, skoro twierdzi się, iż obecnie żyjemy w czasach migracji (Castles, Miller, 2012), to prawdopodobieństwo systematycznego powiększania się grup zmarginalizowanych jest jak najbardziej realne.

Jednocześnie wydaje się, iż zasygnalizowane zagadnienie ograniczania szans na rynku pracy określonych grup jest kluczowe w kontekście ogólnego procesu marginalizacji społecznej, gdyż w konsekwencji ogranicza przecież dostęp do pozostałych sfer instytucjonalnych, jak np. konsumpcji, edukacji, opieki zdrowotnej czy kultury (Poławski, 2005, s. 271). Zatem choćby w imię spójności społecznej, państwo musi stosować skuteczne strategie przeciwdziałania wyłączaniu z rynku pracy wspomnianych segmentów społecznych.

Pytanie, które warto w tym miejscu postawić brzmi - w jaki sposób polityka społeczna powinna realizować efektywne działania $\mathrm{w}$ tym zakresie? Zasygnalizowane zostało wyżej, iż problem to złożony, zatem poruszając się tym tropem, już intuicyjne wydaje się, iż państwo powinno stosować strategię wieloaspektową, uwzględniającą wielowymiarowość zagadnienia. Kierując się tą sugestią, w niniejszym artykule przedstawiamy innowacyjną, „dwukierunkową" strategię przeciwdziałania marginalizacji grup mniejszościowych na rynku pracy. Za przedmiot analizy posłużą dwie grupy mniejszościowe ${ }^{2}$ - Romowie (w Polsce) oraz Żydzi ortodoksyjni (w Izraelu) 3 . Wybór wskaza-

${ }^{2} \mathrm{~W}$ niniejszej analizie stosujemy na ogół termin „grupa mniejszościowa”, oznaczający segment społeczny będący mniejszy ilościowo od reszty społeczeństwa oraz różniący się od większości populacji określonymi cechami. Tak (ogólnie) zaprojektowana kategoria pozwoli na realizację celu w postaci propozycji (ogólnego) schematu procesu marginalizacji społecznej, obejmującego nie tylko np. mniejszości etniczne (np. Romów), ale także wszelkie inne grupy znacząco wyróżniające się ze społeczeństw (np. skrajnie religijnych Żydów ortodoksyjnych).

${ }^{3}$ Mając świadomość, iż Romowie w Polsce tworzą bardzo niejednorodną grupę społeczną, składającą się z przynajmniej czterech podgrup (Polska Roma, Lowarzy, Kełderasze oraz Bergitka 
nych segmentów społecznych ma rzecz jasna swoje uzasadnienie analityczne. Otóż, zarówno polscy Romowie jak i izraelscy Żydzi ortodoksyjni znajdują się w niezwykle trudnej - wręcz fatalnej - pozycji na (właściwym dla siebie) rynku pracy; ponadto obie grupy charakteryzują się specyficznymi cechami wewnątrzgrupowymi, znacznie odróżniającymi ich od reszty społeczeństwa, a przez to - nie ma co ukrywać - poważnie utrudniającymi ich komunikację z otoczeniem społecznym. Konstelacja tych właściwości powoduje, iż sytuacja tych osób, rozpatrywana pod kątem społeczno-ekonomicznym, jest niezwykle skomplikowana. Ryzykujemy nawet hipotezę, że owo położenie jest jednym z najtrudniejszych ze wszystkich segmentów społecznych funkcjonujących we wskazanych państwach ${ }^{4}$. Stąd wydaje się być właściwe budowanie ogólnego modelu marginalizacji na rynku pracy w oparciu o przypadki najbardziej złożone, gdyż to one z jednej strony ukazują niekorzystny dystans zaistniały w społeczeństwie, a z drugiej - wymagają największych nakładów ze strony polityki publicznej.

\section{Romowie w Polsce oraz Żydzi ortodoksyjni w Izraelu - dane ilościowe}

Według spisu powszechnego z 2011 roku związki z tożsamością romską odczuwało zaledwie nieco ponad 17 tys. Polaków (Ludność. Stan i struktura demograficzno-społeczna, 2013, s. 260). Oficjalne szacunki podają, iż stan liczebny tej mniejszości etnicznej może dochodzić do 20 tys. osób, jednak zdaniem osób zajmujących się tą tematyką, rzeczywista liczba Romów w Polsce jest znacznie wyższa niż oficjalne dane i oscyluje w granicach 30-35 tys. osób (Kwadrans, 2013, s. 183) lub nawet dochodzi do 42 tys. (Chrabąszcz, Gałecki, 2010, s. 29). Jak wspomniano we wstępie, sytuacja Romów na rynku pracy jest fatalna. Dane z pierwszej dekady XXI wieku mówią, iż w ponad 40 proc. rodzin romskich w Polsce nie było żadnej osoby aktywnej zawodowo (Kwadrans, Maroń, 2010, s. 107). Prowadzone mniej więcej w tym samym czasie na terenie województwa małopolskiego badania Małgorzaty Leśniak potwierdziły, iż wśród badanych Romów najliczniejszą grupę stanowili bezrobotni - aż 48,6

Roma) (Ficowski, 1985), na potrzeby niniejszej analizy zupełnie wystarczające będzie (uproszczone) łączne traktowanie wspomnianych grup. Podobnie rzecz ma się ze społecznością ortodoksyjną w Izraelu, którą tworzą grupy chasydzkie, litewskie i sefardyjskie (Grupińska, 2000).

${ }^{4}$ Zgadzamy się ze słowami Łukasza Kwadransa, iż Romowie są „najbardziej bezbronną i równocześnie najbardziej niechcianą wśród europejskich mniejszości” (Kwadrans, 2013a, s. 57). 
proc. (2009, s. 47). Sądzimy, iż bardzo ostrożnie szacując, można założyć, iż bezrobocie wśród Romów w Polsce sięga minimum 40 proc. dorosłej populacji w tej grupie społecznej.

Pod względem liczebności izraelscy Żydzi ortodoksyjni znacznie przewyższają polskich Romów. Otóż w 2010 r. ich ilość wyliczono na poziomie 800 tys. osób, co oznaczało, iż stanowili 10,5 proc. społeczeństwa izraelskiego (Bystrov, Soffer, 2013, s. 60). Co niezwykle istotne przy tym wątku, to fakt, iż jest to grupa charakteryzująca się bardzo wysokim poziomem dzietności (średnio około 6,0 w ostatniej dekadzie), w związku z czym szacuje się, iż w 2030 r. ten segment społeczny będzie stanowił już 15 proc. ogółu Izraelczyków (Bystrov, Soffer, 2013). Jednak podobnie jak polscy Romowie, Żydzi ortodoksyjni w Izraelu znajdują się w tragicznym położeniu na rynku pracy (Chaczko, 2014a). W 2010 r. bezrobocie wśród kobiet ortodoksyjnych wyniosło prawie 38 proc., zaś wśród mężczyzn aż ponad 57 proc. (Bank of Israel, 2013, s. 273). Z tego też powodu, ten segment społeczny należy - obok izraelskich Arabów - do najbardziej ubogich grup społecznych w państwie żydowskim (Barkali, 2012; Ben-David, 2014; Chaczko, 2014).

To tyle jeśli chodzi o dane statystyczne. Mając je rzecz jasna cały czas na oku, spróbujemy w dalszym ciągu tekstu scharakteryzować specyficzne cechy omawianych grup społecznych, by na ich podstawie zaproponować ogólny model marginalizacji grup mniejszościowych na rynku pracy.

\section{Romowie w Polsce oraz Żydzi ortodoksyjni w Izraelu - cechy wewnątrzgrupowe}

W literaturze przedmiotu istnieją liczne wskazówki informujące o charakterze granic występujących pomiędzy grupami mniejszościowymi a resztą społeczeństwa. W przypadku Romów, Matt Salo wyróżnił następujące kryteria odróżniające tę grupę społeczną od nie-Romów (gadziów):

- Po pierwsze, kryterium pokrewieństwa, oznaczające naturalne członkostwo w grupie romskiej;

- Po drugie, kryterium wiążące się z kategorią skalania, określającą rzeczy zakazane Romom a przynależne nie-Romom. Uważa się, iż to właśnie to kryterium jest najistotniejsze w wyznaczaniu granicy pomiędzy Cyganami a resztą społeczeństwa (Godlewska-Goska, Kopańska, 2011, s. 183); 
- Po trzecie, kryterium językowe, oznaczające symboliczne oddzielenie od świata nierozumiejącego języka romani;

- Po czwarte, kryterium związane z obowiązującymi normami i nakazami funkcjonującymi w ramach struktury tej grupy społecznej;

- Po piąte, kryterium określające „pewien wzór cygańskiej aktywności ekonomicznej, nastawionej na eksploatowanie świata gadziów, nie-Cyganów (...) Wzór ten zakłada dużą mobilność przestrzenną, unikanie stałego zatrudnienia, niezależność w wyborze rodzaju pracy" (Mirga, Mróz, 1994, s. 269).

- I po szóste, kryterium odnoszące się do (odmiennych) cech zewnętrznych, np. cech antropologicznych, ubioru, określonych gestów itp. (Mirga, Mróz, s. 1994).

Z kolei Łukasz Kwadrans wymienia następujące czynniki decydujące o odrębności społecznej Romów: ciągłość historyczna oparta o doświadczenie pozostawania obcym przybyszem w krajach zamieszkiwania; endogenność, izolacja oraz separacja w przestrzeni społecznej; wyższość wewnętrznych kodeksów postępowania nad prawem obowiązującym w kraju przebywania; brak aspiracji do tworzenia autonomii terytorialnej; marginalizacja oraz alienacja wynikająca $z$ niedostosowania społecznego czy też słabej znajomości języka większości (Kwadrans 2013a, s. 47-48).

Jeśli zaś chodzi o izraelskich Żydów ortodoksyjnych, to np. Oz Almog przytacza szereg kryteriów wyróżniających tę grupę społeczną:

- Religijność totalna, oznaczająca opieranie się we wszystkich sferach życia codziennego na wierze judaistycznej;

- Wierne wypełnianie przykazań judaizmu, czyli ścisłe przestrzeganie licznych reguł postępowania wywodzących się z konserwatywnej wykładni prawa religijnego;

- Wszechobejmująca kontrola społeczna, oznaczająca wewnątrzgrupowe, restrykcyjne i stałe nadzorowanie określonych zachowań jej członków;

- Traktowanie nauki Tory jako wartości najwyższej;

- Podległość uczonemu w piśmie, sprowadzająca się do niemal całkowitego podporządkowania elitom rabinicznym;

- Konserwatywny światopogląd oparty na podkreślaniu różnic dzielących sektor ortodoksyjny od pozostałych („obcych”) grup społecznych;

- Odrzucenie idei syjonistycznej, sprowadzające się w większości przypadków do nieuznawania państwa Izrael. 
- Społeczna izolacja, hermetyczność i cenzura, oznaczająca duchowe i fizyczne zamknięcie oraz trzymanie się własnych enklaw społecznych (Almog, 2011, s. 122-125).

Eli Berman twierdzi z kolei, iż osoby należące do grupy ortodoksyjnej wyróżniają się przede wszystkim pod względem rygorystycznego przestrzegania religijnych zwyczajów pochodzących wprost z XIX-wiecznych, środkowo-europejskich miasteczek (sztetli) w związku z czym odrzucają niemal wszystkie objawy współczesnej kultury oraz wrogo odnoszą się do postępu we wszelkich elementach życia społecznego (Bergman, 2000, s. 910-911).

Mając na uwadze powyższe sugestie, na potrzeby niniejszej analizy zaprojektowane zostały następujące kategorie określające specyfikę omawianych grup społecznych: a) aktywność publiczna; b) wykształcenie; c) język; d) kodeks postępowania; e) kategoryzacja „swój-obcy” (połączona z kategorią „Czyste-nieczyste”); f) przywiązanie do określonych zawodów; g) cechy zewnętrzne. Tabela 1. przedstawia zbiorcze zestawienie powyższych kryteriów $\mathrm{z}$ ich krótkim opisem.

Tabela 1. Kryteria wyróżniające Romów (w Polsce) oraz Żydów ortodoksyjnych (w Izraelu)

\begin{tabular}{|c|c|c|}
\hline & $\begin{array}{l}\text { ROMOWIE } \\
\text { (POLSKA) }\end{array}$ & $\begin{array}{l}\text { ŻYDZI ORTODOKSYJNI } \\
\text { (IZRAEL) }\end{array}$ \\
\hline 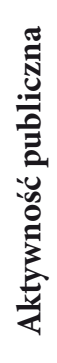 & $\begin{array}{l}\text { Niska } \\
\text { (Niechęć i nieufność do instytucji } \\
\text { publicznych wynikająca m.in. } \\
\text { z prześladowań oraz prób } \\
\text { przymusowej asymilacji. } \\
\text { Tradycyjna struktura } \\
\text { organizacyjna oparta na więziach } \\
\text { rodzinnych i rodowych) }\end{array}$ & $\begin{array}{l}\text { Niska } \\
\text { (Antysyjonizm, czyli odrzucenie } \\
\text { świeckiej idei syjonistycznej, na } \\
\text { gruncie której powołano Izrael. } \\
\text { Stronienie od udziału w obszarze } \\
\text { publicznym oraz nieuczestniczenie } \\
\text { w obowiązkowej służbie wojskowej. } \\
\text { Struktura organizacyjna oparta na } \\
\text { więzach grupowo-rodzinnych) }\end{array}$ \\
\hline 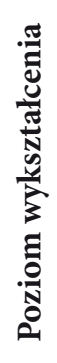 & $\begin{array}{l}\text { Niski } \\
\text { (Szacuje się, iż około } 70 \text { proc. } \\
\text { dzieci romskich objętych jest } \\
\text { edukacją, a ich frekwencja w szkole } \\
\text { jest na niskim poziomie. Większość } \\
\text { Romów kończy edukację na } \\
\text { poziomie podstawowym) }\end{array}$ & $\begin{array}{l}\text { Niski (niereligijny) } \\
\text { (Wybitne wykształcenie religijne, } \\
\text { realizowane nierzadko przez } \\
\text { niemal całe życie ortodoksyjnego } \\
\text { mężczyzny, ale nieadekwatne } \\
\text { do współczesnego rynku pracy. } \\
\text { Brak kompetencji z matematyki, } \\
\text { informatyki oraz wszechobecnego } \\
\text { w Izraelu języka angielskiego) }\end{array}$ \\
\hline
\end{tabular}




\begin{tabular}{|c|c|c|}
\hline 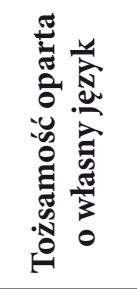 & $\begin{array}{l}\text { Bardzo ważna } \\
\text { (Posługiwanie się we własnym } \\
\text { środowisku oraz przekazywanie } \\
\text { dzieciom języka romani należy } \\
\text { do jednych z najważniejszych } \\
\text { nakazów wewnątrzgrupowych) }\end{array}$ & $\begin{array}{l}\text { Ważna } \\
\text { (Wśród aszkenazyjskich Żydów } \\
\text { ortodoksyjnych tradycja } \\
\text { posługiwania się poza sferą sacrum } \\
\text { językiem jidysz. Język hebrajski } \\
\text { używany głównie w obrządkach } \\
\text { religijnych) }\end{array}$ \\
\hline 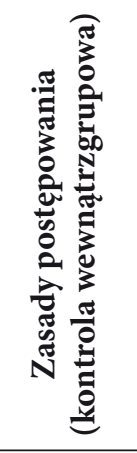 & $\begin{array}{l}\text { Silne (niespisane) } \\
\text { (Kodeks romanipen normujący } \\
\text { zachowania wewnątrzgrupowe } \\
\text { i faktycznie wyznaczający } \\
\text { granice etniczności. Zawiera } \\
\text { w sobie najważniejsze wzorce } \\
\text { postępowania, normy i zasady } \\
\text { współżycia, np. solidarność } \\
\text { współplemienną, manifestowanie } \\
\text { cygańskości czy posługiwanie się } \\
\text { językiem romani ) }\end{array}$ & $\begin{array}{l}\text { Silne (spisane) } \\
\text { (Halacha, czyli zbiór } \\
\text { konserwatywnych zasad } \\
\text { postępowania wywodzący się z } \\
\text { Tory oraz Talmudu. Wyznacza } \\
\text { granicę ortodoksji i reguluje wiele } \\
\text { aspektów życia: od koszernych } \\
\text { zasad pokarmowych po ubiór) }\end{array}$ \\
\hline 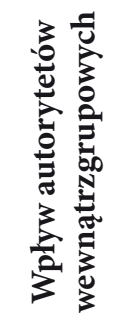 & $\begin{array}{l}\text { Bardzo istotny } \\
\text { (Indywidualny, np. Szero Rom } \\
\text { bądź grupowy - Kris) }\end{array}$ & $\begin{array}{l}\text { Bardzo istotny } \\
\text { (Indywidualny - rabin, } \\
\text { bądź grupowy - np. Rada } \\
\text { Mędrców Tory) }\end{array}$ \\
\hline 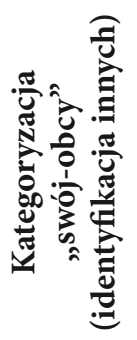 & $\begin{array}{l}\text { Istotna } \\
\text { (Wyraźna dychotomia „my- } \\
\text { oni” [Rom - gadzio] połączona } \\
\text { z kategorią „czyste - nieczyste” } \\
\text { [romanipen - gadzipen]) }\end{array}$ & $\begin{array}{l}\text { Istotna } \\
\text { (Wyraźna dychotomia „my-oni” } \\
\text { [Żyd - goj] połączona z kategorią } \\
\text { „Czyste - nieczyste” [koszerne- } \\
\text { trefne]) }\end{array}$ \\
\hline 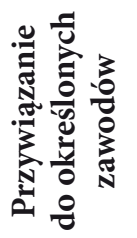 & $\begin{array}{l}\text { Silne } \\
\text { (Handel, muzykowanie. } \\
\text { Występowanie zawodów } \\
\text { zabronionych, np. policjant, } \\
\text { pielęgniarka, rzeźnik) }\end{array}$ & $\begin{array}{l}\text { Silne } \\
\text { (Głównie sektor religijny - } \\
\text { sprzedawca judaików, nauczyciel } \\
\text { w szkole religijnej, rzeźnik } \\
\text { rytualny, perukarka) }\end{array}$ \\
\hline
\end{tabular}




\begin{tabular}{|l|l|l|}
\hline & Widoczne & $\begin{array}{l}\text { Widoczne } \\
\text { (W przypadku mężczyzn - czarna, } \\
\text { materiałowa jarmułka, marynarka, } \\
\text { biała koszula, ciemne spodnie, } \\
\text { czarny kapelusz. W przypadku } \\
\text { kobiet - dominacja barw } \\
\text { ciemnych: długie spódnice, zakryte } \\
\text { ramiona i włosy) }\end{array}$ \\
\hline wystawność: materiałowe spodnie, \\
koszule, marynarki. W przypadku \\
kobiet - długa spódnica, związane \\
włosy)
\end{tabular}

Źródło: Opracowanie własne na podstawie: Almog, 2011; Bartosz, 2004; Berman, 2000; Borzymińska, Żebrowski, 2003; Chaczko, 2014; Ficowski, 1985; Grupińska, 2000; Heilman, Friedman, 1996; Kwadrans, 2013a; Mirga, Mróz, 1997; Paszko, Sułkowski, Zawicki, 2007; Ravitzky, 1996; Shafir, Peled, 2002; Szymańczak, 2011.

Wydaje się, iż esencja niniejszej tabeli sprowadza się do specyfiki kategorii tożsamości etnicznej opisanych grup. Otóż tożsamość ta, zarówno w przypadku Romów jak i Żydów ortodoksyjnych, odnosi się przede wszystkich do reszty społeczeństwa. Na fundamencie tej dychotomii, odpowiednio: Rom - gadzio; Żyd - goj, zbudowana jest granica etniczna, podkreślana i dodatkowo wzmacniana przez kategorię „czyste - nieczyste” (Kwadrans, 2013). W konsekwencji wierne przestrzeganie tradycji przez obie grupy przejawia się nie tylko w przywiązywaniu wielkiej wagi do macierzystych obyczajów i życiu we wspólnotach rodzinnych, ale także w ekskluzywizmie grupowym i przekładaniu własnych, grupowych form organizacji oraz zasad postępowania ponad to co państwowe (Kwadrans 2013, s. 179). Nabyte w ten sposób wzory funkcjonowania są niewątpliwie na tyle odmienne od reszty społeczeństwa, iż bywają przyczyną kulturowego zderzenia (Paszko, Sułkowski, Zawicki, 2007).

\section{Bariery utrudniające wejście na rynek pracy grup mniejszościowych oraz schemat ich marginalizacji}

Kolejny etap niniejszej analizy sprowadzał się będzie do próby opisania barier utrudniających wejście na rynek pracy grup mniejszościowych oraz skonstruowania na ich podstawie ogólnego schematu marginalizacji. W literaturze przedmiotu odnajdujemy rzecz jasna sugestie co do charakteru barier uniemożliwiających mniejszościom społecznym uczestnictwo w sferze społecznej oraz zawodowej. Wymienia się np.: a) brak wykształcenia i umiejętności; b) brak kompetencji językowych; c) brak uznanych umiejętności i kwalifikacji; d) brak dostępu do zawodów; e) brak dostępu do obywatelstwa; f) brak po- 
lityki integracyjnej; g) stereotypy, uprzedzenia i negatywny stosunek; h) brak mobilności; i) zmiany przemysłowe; j) demotywacja wynikająca z działań państwa dobrobytu; k) dyskryminacja; 1) brak informacji; ł) konkurencja na rynku pracy; m) brak ofert pracy ze strony pracodawców (Mazur, Gałecki, 2010, s. 27-28). Poruszając się jednak tropem badawczym Artura Paszki, Rafała Sułkowskiego oraz Marcina Zawickiego, którzy wyróżnili bariery strukturalne, zewnętrzne i wewnętrzne (2007, s. 122-125), pozwolimy sobie pozostać przy zbliżonym, ogólnym nazewnictwie.

Posiadając wiedzę na temat specyficznych cech omawianych grup społecznych można niewątpliwie mówić o istnieniu bariery wewnętrznej, którą konstytuują (opisane wyżej) specyficzne zasady i zachowania wewnątrzgrupowe. Naturalne jest także, iż wspomniane cechy i zwyczaje przynależne interesującym nas segmentom mniejszościowym oddziałują na otoczenie społeczne powodując określone reakcje większości populacji, przez co z pewnością możemy mówić również o barierze zewnętrznej. Warto zatem przyjrzeć się im bliżej.

Barierę wewnętrzną tworzą z jednej strony reguły, przekonania, wartości i zachowania grupowe (wynikające np. wewnętrznych kodeksów postępowań czy kategoryzacji „swój-obcy”), a z drugiej strony, ograniczenia edukacyjno-językowe (np. niskie wykształcenie). Wskazany pierwszy element bariery wewnętrznej, czyli wewnętrzne źródło postępowań grupowych, z pewnością znacznie (auto)ogranicza podejmowanie określonych działań na rynku pracy, czyli faktycznie jest efektem wyboru jednostki bądź grupy i można go określić mianem marginalizacji wewnętrznej (automarginalizacji).

Barierę zewnętrzną z kolei tworzą postawy większości społeczeństwa będące wynikiem odmiennych - i rzecz jasna dominujących w społeczeństwie przyzwyczajeń, zasad i tradycji. Bariera ta, zawierająca $\mathrm{w}$ sobie elementy uprzedzeń czy nieufności budowanych zwykle na ignorancji i stereotypach (Lubecka, 2009), sprowadza się do spadku znaczenia grupy mniejszościowej właśnie z powodów odmiennego postrzegania świata czy nawet samego wyglądu. Tę barierę określić możemy mianem marginalizacji zewnętrznej (społecznej). Syntetyczne zestawienie charakteru obu barier zaprezentowane zostało w tabeli 2. 
Tabela 2. Bariery utrudniające wejście na rynek pracy grup mniejszościowych

\begin{tabular}{|c|c|}
\hline \multirow{2}{*}{ Bariera wewnętrzna } & $\begin{array}{c}\text { Bariera wynikająca z reguł, wartości, przekonań } \\
\text { i zachowań grupowych } \\
\text { (marginalizacja wewnętrzna) }\end{array}$ \\
\cline { 2 - 2 } Bariera zewnętrzna & $\begin{array}{c}\text { Bariera edukacyjno-językowa } \\
\text { Bariera wynikająca z postaw większości społeczeństwa } \\
\text { (uprzedzenia, nieufność, dyskryminacja) } \\
\text { (marginalizacja zewnętrzna) }\end{array}$ \\
\hline
\end{tabular}

Źródło: Opracowanie własne.

Biorą pod uwagę specyfikę wyżej wymienionych barier, możemy spróbować zarysować ogólny schemat marginalizacji grup mniejszościowych na rynku pracy. Otóż ów koncept - przedstawiony na ryc. 1 - zawiera w sobie cztery powiązane ze sobą elementy:

a) zmarginalizowaną grupę mniejszościowa;

b) barierę wewnętrzną;

c) barierę zewnętrzną;

d) rynek pracy.

Ryc. 1. Schemat procesu marginalizacji grup mniejszościowych na rynku pracy

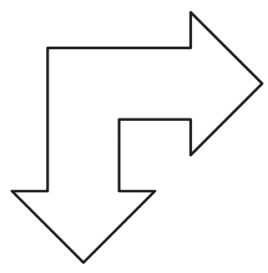

BARIERA WEWNĘTRZNA
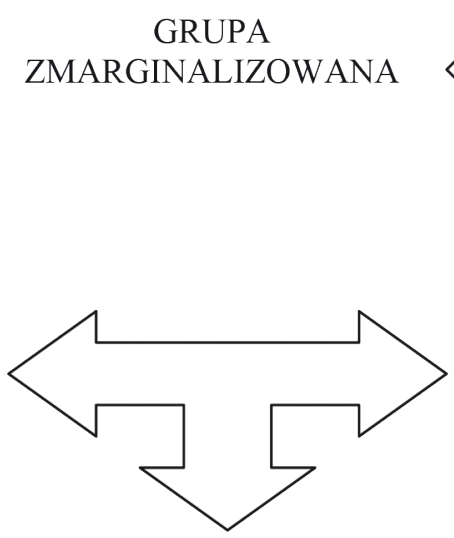

RYNEK

PRACY

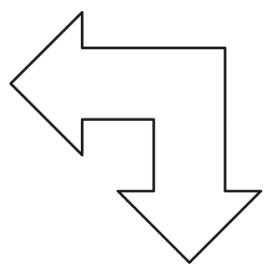

BARIERA ZEWNĘTRZNA

Źródło: Opracowanie własne 
Jakie wnioski można wyciągnąć $\mathrm{z}$ tak ujętego konstruktu teoretycznego?

Po pierwsze, w przypadku grup mniejszościowych mamy do czynienia z występowaniem dwóch znaczących przeszkód w dostępie do rynku pracy, a w związku z czym możemy mówić o istnieniu podwójnej marginalizacji wewnętrznej oraz zewnętrznej.

Po drugie, wydaje się, iż wyszczególnione elementy w istotny sposób wpływają na siebie. Bariera wewnętrzna warunkuje zewnętrzną; ta z kolei wpływa na grupę - co może prowadzić do dodatkowego uszczelniania bariery wewnętrznej. Przy takiej optyce przedstawiony schemat staje się zamkniętym procesem skutecznego wykluczania z rynku pracy.

Po trzecie, z powodów zasygnalizowanych powyżej, wejście na rynek pracy osób należących do grupy marginalizowanej jest szczególnie trudne, gdyż wymaga pokonania aż dwóch rodzajów barier. Specyfika ta jest symptomatyczna właśnie dla grup mniejszościowych, i wydaje się, iż nie występuje - a przynajmniej nie w takim stopniu - w przypadku osób należących do większości społeczeństwa.

\section{Podsumowanie}

Podjęty w pierwszej części artykułu opis cech wyróżniających (dwóch) wybranych grup mniejszościowych miał na celu „zbudowanie” empirycznej podstawy do propozycji ogólnego schematu procesu marginalizacji mniejszościowych segmentów społecznych na rynku pracy. Warto zwrócić przy tym uwagę, iż obie analizowane mniejszości - Romowie w Polsce oraz Żydzi ortodoksyjni w Izraelu - pomimo obiektywnych różnic (także geograficznych), łączy pewna zbieżna specyfika w postaci: elementów kastowości, endogenności, własnych kodeksów postępowań czy rodzinnych systemów organizacji społecznej (Kwadrans, 2013a). Zaryzykowałybyśmy nawet hipotezę, iż wspomniane cechy wspólne mogą być charakterystyczne także dla innych mniejszości narodowych i etnicznych, choć pewnie występują w różnym stopniu i z różnym natężeniem.

W istocie możemy więc założyć, iż skonstruowany na tej podstawie schemat procesu marginalizacji grup mniejszościowych na rynku pracy może mieć pewien walor ogólny. To po pierwsze, a po drugie, projekt ten umożliwia sformułowanie odpowiedzi na postawione we wstępie pytanie - w jaki sposób polityka społeczna powinna realizować efektywne działania w zakresie zwalczania marginalizacji grup mniejszościowych na rynku pracy? 
Uwzględniając powyższe ustalenia, nie trudno dojść do wniosku, iż działania $\mathrm{w}$ tej dziedzinie muszą koncentrować się na niwelacji obu barier. Nie wydaje się, iż likwidacja tylko jednej z barier - wewnętrznej bądź zewnętrznej - będzie wystarczającą przesłanką do tworzenia sprzyjających warunków funkcjonowania segmentów mniejszościowych na rynku pracy. Procesowi tworzenia i realizacji programów mających na celu podnoszenie kwalifikacji zawodowych (umiejętności) czy kreowania miejsc pracy adekwatnych do wewnętrznej specyfiki grup mniejszościowych (elementy bariery wewnętrznej) muszą towarzyszyć równoległe przedsięwzięcia z zakresu wzajemnego postrzegania społecznego (elementy bariery zewnętrznej). Projektując warunki umożliwiające wchodzenie grup mniejszościowych na rynek pracy „trzeba przede wszystkim zadbać o zmniejszenie społecznego dystansu między nimi a grupą większościową poprzez podniesienie w (...) tych grupach poziomu wiedzy o sobie wzajemnie i poziomu obopólnej akceptacji” (Paszko, Sułkowski, Zawicki, 2007, s. 127).

Inaczej mówiąc, realizacja działań w tym zakresie powinna zakładać strategię (przynajmniej) dwukierunkową, nastawioną na likwidację bariery wewnętrznej oraz zewnętrznej. Tylko wtedy będzie możliwość uzyskania - jak to nazwała Anna Lubecka - „wartości synergicznej”, a przez to szansy na jakościowe zmiany nie tylko wśród grupy mniejszościowej ale całego społeczeństwa. Podstawą tych działań powinny być „wzajemne związki pomiędzy ekonomią i kulturą, pomiędzy dyskryminacją ekonomiczną a dyskryminacją etniczną i osobistą (...) Jedynie w takim ujęciu jest ona szansą do budowania dialogu społecznego przeciwdziałającego wykluczeniu i marginalizacji społecznej grup mniejszościowych, jest sposobem ich aktywizacji zawodowej, budowania spójności społecznej oraz skutecznym narzędziem do poprawy jakości życia samych mniejszości i całego społeczeństwa" (Lubecka, 2001, s. 99).

Uwaga ta nabiera szczególnego znaczenia w kontekście realizacji działań skierowanych do grupy polskich Romów. Otóż wydaje się, iż działania polityk publicznych w tym zakresie cechuje niekompleksowość, a związku z czym niska skuteczność. Realizowane w Polsce od ponad dekady liczne programy na rzecz społeczności romskiej skupiają się głównie na obszarach edukacyjno-zawodowych (bariera wewnętrzna) z rzadka podejmując aspekt postrzegania międzykulturowego (bariera zewnętrzna) (Mirga-Wójtowicz, 2013; Zwierzyńska, 2013). Stąd zupełnie uzasadniona jest opinia, iż „konieczne jest odejście od filozofii pojedynczych projektów na rzecz podejścia zintegrowane- 
go, uwzględniającego wszystkie aspekty wykluczenia” (Mazur, Gałecki, 2010, s. 35). Jeszcze raz okazuje się zatem, iż banalne stwierdzenie w postaci: wielowymiarowa kwestia społeczna wymaga wielowymiarowych działań publicznych, odnosi się do zupełnie niebanalnych problemów.

Streszczenie: Skoro twierdzi się, iż polityka społeczna powinna rozwiązywać istotne problemy społeczne - a za taki problem uważa się proces marginalizacji grup mniejszościowych na rynku pracy - to działania publiczne w tym zakresie powinny cechować się skutecznością. Aby spróbować odpowiedzieć na pytanie: jak powinny wyglądać skuteczne działania w tym zakresie?, w pierwszej części artykułu opisano cechy wewnątrzgrupowe (wyróżniające) dwóch segmentów mniejszościowych - Romów w Polsce oraz Żydów ortodoksyjnych w Izraelu. Ustalenia te posłużyły do omówienia - w drugiej części artykułu - barier utrudniających funkcjonowanie grup mniejszościowych na rynku pracy oraz zaproponowania ogólnego schemat marginalizacji grup mniejszościowych. Artykuł kończą rozważania na temat „dwukierunkowej” strategii przeciwdziałania wykluczenia grup mniejszościowych z rynku pracy

Słowa kluczowe: marginalizacja, grupy mniejszościowe, rynek pracy, polityka społeczna

Abstract: This paper describes the strategy of counteraction of minority groups marginalization on the labor market. Social policy should solve major social problems, and the minority groups marginalization on the labor market is a major social problem. The first part of this paper describes the features of the two minority groups - Roma in Poland and Orthodox Jews in Israel. The second part of the paper discusses the barriers to the functioning of minority groups in the labor market, and suggests diagram of minority groups marginalization on the labor market. The article ends with conclusions on the actions of social policies in this area.

Keywords: marginalization, minority groups, labor market, social policy 


\section{Literatura przedmiotu}

Almog, O. (2011). Wielokulturowy Izrael. Warszawa: Wydawnictwo WSP TWP. Bank of Israel. (2013). Annual Report 2012. Jerusalem: Maor Wallach Printing. Barkali, N. i in. (2012). Poverty and Social Gaps 2011. Annual Report. Jerusalem: National Insurance Institute.

Bartosz, A. (2004). Nie bój się Cygana. Na dara Romestar. Sejny: Pogranicze.

Ben-David, D. (2014). A Picture of the Nation. Israel's Society and Economy in Figures 2014. Jerusalem: Taub Center for Social Policy Studies in Israel.

Berman, E. (2000). Sect, Subsidy, and Sacrifice: An Economist's View of Ultra-Orthodox Jews. The Quarterly Journal of Economics, 3 (115), 905-953.

Borzymińska, Z., Żebrowski, R. (red.) (2003). Polski Słownik Judaistyczny, t. 1-2. Warszawa: Prószyński i S-ka.

Bystrov, E., Arnon, S. (2013). Israel: Demography 2013-2034. Challenges and Chances. Haifa: University of Haifa.

Castles, S., Miller, M.J. (2012). Migracje we wspótczesnym świecie. Warszawa: PWN.

Chaczko, K. (2014). Ubóstwo w społeczeństwie wielokulturowym. Przykład religijnej grupy ultraortodoksyjnej w Izraelu. Polityka Społeczna, 1 (478), 18-23.

Chaczko, K. (2014a). „Wielokulturowa (bez)robotność”. Rzecz o izraelskim rynku pracy. Labor et Educatio, 2, 49-63.

Chrabąszcz, R., Gałecki, A. (2010). Rozmieszczenie terytorialne społeczności romskiej w Polsce. W: S. Mazur (red.), Krajowe i wspólnotowe polityki publiczne wobec mniejszości romskiej - mapa aktywności społeczno-gospodarczej Romów (23-47). Kraków: Małopolska Szkoła Administracji Publicznej Uniwersytetu Ekonomicznego w Krakowie.

Craig, G. (2002). Ethnicity, Racism and the Labour Market: a European Perspective. W: J.G. Andersen, P.H. Jensen (red.), Changing Labour Markets, Welfare Policies and Citizenship (149-181). Bristol: Policy Press.

Danecki, J. (2001). Kwestia społeczna. W: B. Rysz-Kowalczyk (red.), Leksykon polityki społecznej (77-80), Warszawa: Oficyna Wydawnicza ASPRA-JR.

Ficowski, J. (1985). Cyganie na polskich drogach. Kraków: Wydawnictwo Literackie.

Godlewska-Goska, M., Kopańska, J. (2011). Życie w dwóch światach. Tożsamość wspótczesnych Romów. Warszawa: Wydawnictwo DiG.

Grupińska, A. (2000). Najtrudniej jest spotkać Lilit. Opowieści chasydek. Warszawa: Twój Styl.

Heilman, S. C., Friedman, M. (1996). The Haredim in Israel: Who Are They and What Do They Want?. Jerusalem: The American Jewish Committee.

Jasińska-Kania, A., Łodziński, S. (2008), Wykluczani z narodu: mniejszości narodowe, migranci, uchodźcy. W: M. Jarosz (red.), Wykluczani. Wymiar społeczny, materialny i etniczny (243-153). Warszawa: Instytut Studiów Politycznych PAN. 
Kołaczek, M. (2013). Wpływ integracji europejskiej na etniczną mobilizację Romów - przykład Węgier. W: J. Balvin, Ł. Kwadrans, H. Kyuchukov (red.), Roma in Visegrad Countries: History, Culture, Social Integration, Social Work and Education (87-112). Wrocław: Foundation of Social Integration Prom.

Kowalak, T. (2001). Marginalizacja społeczna. W: B. Rysz-Kowalczyk (red.), Leksykon polityki społecznej (87-89). Warszawa: Oficyna Wydawnicza ASPRA-JR.

Kwadrans, Ł. (2013). Romowie. Bliscy - Nieznani. Jedni z wielu... W: J. Balkowski (red.), Romarising. Bohaterowie kampanii społecznej „Jedni z wielu” w obiektywie Chada Evansa Wyatta (178-197). Wrocław: Fundacja Integracji Społecznej Prom.

Kwadrans, Ł. (2013a). Tożsamość romska - refleksja socjologiczna. W: J. Balvin, Ł. Kwadrans, H. Kyuchukov (red.), Roma in Visegrad Countries: History, Culture, Social Integration, Social Work and Education (39-58). Wrocław: Foundation of Social Integration Prom.

Kwadrans, Ł., Maroń, S. (2010). Poziom kapitału społeczno-zawodowego Romów w Polsce. W: M. Zawadzki, A. Paszko (red.), Polityka wspierania romskiej mniejszości etnicznej na rynku pracy (97-113). Kraków: Małopolska Szkoła Administracji Publicznej Uniwersytetu Ekonomicznego w Krakowie.

Leśniak, M. (2009). Romowie. Bliscy czy dalecy? Realizacja zadań w ramach Rządowego Programu na Rzecz Społeczności Romskiej w Polsce. Kraków: Publisher.

Lister, R. (2007). Bieda. Warszawa: Sic!

Lubecka, A. (2009). Postawy Polaków wobec pracy a mniejszości na polskim rynku pracy, Zarzadzanie Publiczne, 5, 87-101.

Ludność. Stan i struktura demograficzno-społeczna. (2013). Narodowy Spis Powszechny Ludności i Mieszkań 2011. Warszawa: Główny Urząd Statystyczny.

Mazur, S., Gałecki A. (2010). Romowie we wspólnotowych i krajowych politykach rynku pracy. W: M. Zawadzki, A. Paszko (red.), Polityka wspierania romskiej mniejszości etnicznej na rynku pracy (13-36). Kraków: Małopolska Szkoła Administracji Publicznej Uniwersytetu Ekonomicznego w Krakowie.

Mirga, A., Mróz, L. (1994). Cyganie. Odmienność i nietolerancja. Warszawa: PWN.

Mirga-Wójtowicz, E. (2013). Program pomocowy dla społeczności Romów w Polsce - osiągnięcia i wyzwania. Przykład Małopolski. W: P. Borek (red.), Studia o Romach w Polsce i Europie (91-111). Kraków: Wydawnictwo Naukowe Uniwersytetu Pedagogicznego.

Paszko, A., Sułkowski, R., Zawicki, M. (2007). Romowie na rynku pracy. Kraków: Małopolska Szkoła Administracji Publicznej Uniwersytetu Ekonomicznego w Krakowie.

Poławski, P. (2005). Marginalność społeczna i wychowanie. W: Polityka Społeczna. Wybrane problemy. Wybór artykutów z lat 1999-2005 (270-279). Warszawa: Instytut Pracy i Spraw Socjalnych.

Ravitzky, A. (1996). Messianism, Zionism, and Jewish Religious Radicalism. Chicago: University of Chicago Press. 
Shafir, G., Peled, Y. (2002). Being Israeli. The Dynamic of Multiple Citizenship. Cambridge: Cambridge University Press.

Szymańczak, J. (2011). Społeczność Romów w Polsce. Warszawa: Biuro Analiz Sejmowych.

Zwierzyńska, K. (2013). Romskie odrodzenie. W: J. Balvin, Ł. Kwadrans, H. Kyuchukov (red.), Roma in Visegrad Countries: History, Culture, Social Integration, Social Work and Education (451-462). Wrocław: Foundation of Social Integration Prom.

Data przesłania artykułu do Redakcji: 12.09.2017 r.

Data akceptacji artykułu: 12.12.2017 r. 